\title{
Restructuring retail property markets in Central Europe: impacts on urban space
}

\author{
Herman J. Kok
}

Received: 20 November 2006/ Accepted: 20 November 2006/ Published online: 23 February 2007 (C) Springer Science+Business Media B.V. 2007

\begin{abstract}
This paper discusses the changing retail property structures in Central Europe in the aftermath of the integration of these countries in the global economy. In general, within the property market, retail real estate is the market sector that is most affected by internationalization. Therefore, this sector is relatively transparent compared to the office and residential markets. The macro-economic transitions in Central Europe and the integration of these countries in the world economy opened these markets to international retailers. As a result, the retail scene in these countries, combined with the structure of the retail property stock, has changed dramatically. In the late 1990s, Central Europe experienced a retail development boom driven by international hypermarket operators and speculative developers. Shopping centers and hypermarkets became important elements in the urban landscape. However, lack of planning and vision led to chaotic development, and oversupply was the outcome. In the future, public and private actors will need a vision of how the city should develop before embarking on flagship urban projects.
\end{abstract}

Keywords Retail - Property markets - Central Europe $\cdot$ Shopping centers · Hypermarkets

Author is member of European Research Group ICSC International Council Shopping Centers.

H. J. Kok (ه)

Multi Development, Hanzeweg 16, P.O. Box 875, 2800 AW Gouda, The Netherlands

e-mail: hkok@multi-development.com www: www.multi-development.com 


\section{Introduction}

Anyone visiting Budapest, Warsaw, or Prague after the accession of Central Europe into the European Union will be struck by the large number of shopping centers and hypermarkets but also by the variety of international retail shops in the malls and high streets. The globalizing retail market leaves its mark on Central Europe by creating a retail landscape that is more international than found in most mature markets, including the UK, France, and Germany. Anyone visiting Central Europe's capital cities would find it hard to imagine that just 20 years ago Central Europe was still dominated by a socialist centrally planned economy. During the socialist era, the retail structure was defined by state and cooperative entities. The variety of merchandise was limited, and some countries, including Poland, even had shortages. Modern shopping malls and hypermarkets were non-existent in those days.

In general, markets in which an economic transition and reorientation to the outside world took place have experienced a rapid restructuring and internationalization of the retail landscape. Though Central Europe is a prime example of this process, a similar phenomenon may be found in Spain and Portugal, Greece and Turkey, in Asian markets such as China and India, and more recently in Russia and the Ukraine. However, the rapid restructuring of the retail market and the strong influence of international capital makes Central Europe a remarkable case.

In Central Europe, the transition from a centrally planned economy to a market economy and the subsequent internationalization had an enormous impact on the retail trade in Central Europe. Most of the leading retail chains in the market are currently under foreign ownership. The three key elements of the retail restructuring-privatization of state and cooperative retail; formation of private retail businesses; and massive entry of international retailers into the market (Deiters, 2000)—have completely overhauled the retail market in Central Europe.

The overhaul of the retail trade has already had a dramatic impact on the urban retail structure and will have an impact on future urban redevelopment and rehabilitation projects, especially in the capital cities. As the dynamics of the retail trade shifted from central planning to the market, it became obvious that the urban retail structure-defined by its pre-socialist history and socialist planners - was obsolete. The enormous gap between the spatial demands of modern retail trade and the existing available space attracted many local and international developers into the retail development market. Leading largearea retailers-such as (international) operators of hypermarkets, cash-andcarry stores, do-it-yourself stores, and IKEA furniture stores-developed their own premises, often including additional space to be leased to other retailers. Shopping centers and hypermarkets became the nodes of retail and consumption in the capital cities of Central Europe.

As such, the retail sector underwent dramatic changes in the period between the collapse of the socialist regimes and the accession to the EU. Since 
the mid-1990s, Central Europe has become the main target for international retailers, developers and property investors. This article discusses the impact of changing retail trade on the urban retail structure in Central Europe in the aftermath of the integration of these countries in the global economy. The key questions addressed in this paper are the following:

- How did socialist ideology and pragmatism shape the retail sector in Central Europe during the period of central planning?

- How did the different mechanism of the transition from state to market affect the retail structure?

- How was the retail structure impacted by globalization that proceeded by means of the internationalization of retail in Central Europe?

- What were the consequences of the transition and internationalization of retail on the urban landscape?

The first and second questions are dealt with in a more general way, while the third question is discussed by taking Budapest as an example.

\section{Retail in the socialist era}

After 1945, cities in Hungary and Poland remained under a command economy for almost 45 years. The communist ideology held that retail was no more than a distribution outlet whereby consumer goods produced by manufacturing and agriculture could be made available to the population (Earle, Frydman, Rapaczynski, \& Turkewitz, 1994). Whether or not retail trade added to national production was heavily disputed. Planners and ideologists saw consumer demand as highly suspicious because it was impossible to dictate and difficult to manipulate. As a result, retail trade got low priority compared to other sectors such as manufacturing and infrastructure.

In general, retail trade in the socialist economies in Central Europe was managed by state and cooperative retail chains, which were responsible for the allocation of consumer goods to the population. The overall retail sector was highly fragmented. Different sections of the retail trade fell under the responsibility of different ministries, depending on the products sold. And some parts of the retail trade were decentralized to the level of the province or city (Earle et al., 1994). There was no single ministry or state organization responsible for retail trade. Besides, many large industrial companies and institutions had their own in-company stores to supply their workers and employees with consumer goods. These company stores accounted for a considerable share of the total retail turnover.

The efficiency of state and collective retail systems in Central Europe varied country by country. The state-dominated system in its traditional form was most effective in the former Czechoslovakia, where consumer demand could be met to a certain extent. In Hungary, reforms in the retail system had already started in the late 1960s (Earle et al., 1994). There, retail networks got 
significant levels of autonomy and a limited freedom to set prices in the end, even to the point of competing with each other. Therefore, compared to elsewhere in Central Europe, cooperative retail chains in Hungary were relatively modern and efficient. In contrast, the state retail system in Poland was extremely weak and inefficient (Earle et al., 1994). Stock and inventory tended to be very poor in Poland; empty stores, shortages and long lines in front of the shops were common.

Depending on the way different countries interpreted the ideology, private entrepreneurs were allowed to be involved in retail trade. Hungary and Poland were among the more flexible countries, allowing private businesses limited opportunities in retailing. The former Czechoslovakia adhered to the traditional ideology till the collapse of the socialist political system.

Compared to Western Europe, the supply of retail stores was weak in Central Europe, both in terms of number of stores per 1,000 inhabitants and in sales area. Because of the low priority of retail trade in the ideology, the limited supply and variety of merchandise, the low number of retail chains, and the impact of in-company retail, cities and towns in Central Europe tended to have an undersupply of retail space.

There were different levels of efficiency in state-led retailing. Moreover, the legislative environment for the retail sector differed across Central Europe. Accordingly, the retail legacy left by the centrally planned system differed between the countries. Retail in Poland was about to collapse; Hungarian retail was quasi-adapted to 'market conditions'; and the Czechoslovak system was the most efficient.

\section{Retail in socialist urban planning}

The development of retail locations in Central Europe under socialism was strongly linked to socialist principles of urban planning and land allocation. Central European cities were characterized by an absence of real estate markets and land prices. This had a major impact on the structure of socialist cities (Bertaud, 2004). Densities and land allocation for different uses-mainly industrial and residential, but also services and retail-did not reflect consumer demand. Instead, they were based largely on administrative decisions aimed at minimizing input rather than maximizing values (Kornai, 1992). The most important principle of socialist planning is that land has no monetary value per se (Bertaud \& Renaud, 1995). Land was allocated on a 'per need basis'. Planning norms would establish the amount of land required to build factories or apartments as well as shops and services. The 'per need basis' was expressed as a normative number of units or amount of space. The location was defined administratively, and distance from the city center was not a criterion. Because of the low priority that retail had in the ideology and because part of the retail was supplied through factories and institutions, space for retail supply was structurally under-allocated (Bertaud, 2004). 
The location of retail outlets was determined by urban planners on a "per need basis' as defined by higher economic planning institutions. The choice of a retail location was based on a hierarchy. The highest level of retail consisted of department stores, for instance, which were concentrated in central city areas, whereas retail outlets supplying basic needs were located in residential areas (Garb \& Dybicz, 2006). These were either at the heart of the housing estate, within easy pedestrian access for the inhabitants, or else they were located at or nearby public transport nodes. Because of the low number of retailers and the limited variety of merchandise, as well as the high share of gray chains of retail such as factory shops for the workers, both city center and suburban retail areas were limited in size and number of outlets. Typical anchor stores in central city areas were department stores. Each relatively large town had at least one department store. In general, the bigger the town, the bigger, better supplied and more prestigious the department store will be.

Retailing did not have high priority in the budgets for development. Therefore, retail facilities arrived at the very last phase of the development of housing estates or not at all. This is why the consumer goods in the housing estates and suburban areas tended to be in the shortest supply and of the lowest quality of anyplace within the city. Because of the moderate levels of car ownership and the limited use of private cars, car access was hardly a consideration when choosing a location for retail outlets. At a later stage, in the late 1970s and 1980s, Hungary experimented with district centers. Located at strategic public transport nodes, these served both basic convenience needs and needs for non-food durables. The two first 'socialist' shopping centers in Budapest, namely Florián (Obuda) and Sugár (Zuglo), were built with these ideas in mind. Most of the Hungarian cooperative retail chains that did attain a position in the market took up space in these centers.

\section{Transition of the retail market}

A fundamental change in the retail trade set in immediately after the political shift. The previously nationalized and centralized system of goods distribution was gradually replaced by a market economy (Kreja, 2004). The economic transition includes a wide range of changes: the shift from an agrarianindustrial economy to a service economy; the shift from a planned economy to a market economy; the shift from a socialist to a mixed economy, from a closed to an open economy, and from a shortage to a surplus economy. Taking these changes into account, the retail sector was among the first to be transformed completely.

In short, the transition included the privatization of state and cooperative retail outlets, putting them in the hands of private entrepreneurs; a rapid establishment of new private retail businesses; and the entry of foreign retailers into the market (Deiters, 2000). As Bertaud (2004) observed, the systematic under-allocation of land for retail and services gave rise at the time of the transition to an invasion of 'shops in a container' often called 'kiosks', 
doing business on sidewalks and in public parks. Meanwhile, many shops were established in basements with openings at the sidewalk level.

The political and economic transition started in the aftermath of the political turnaround. The economic transition consisted of three major processes (Sýkora, 1994), which provided the tools for the restructuring and overhaul of the retail trade:

- Deregulation of allocation of assets

- Liberalization of prices

- Privatization of state and collectively owned assets.

One impact of the political transformation was particularly relevant to retail development. That was the decentralization of decision-making from the central (i.e., national) level to the local (i.e., municipal) level. Municipal authorities were put in charge of decision-making on planning and development as well as issuing construction permits. This had a limited impact in the aftermath of the turnaround. However, the impact was substantial at the time of rapid development of shopping centers and hypermarkets. Because of the ambition, the prestige, the perspective of attracting investments and employment, as well as the limited experience and vision with respect to retail markets and development, the municipal authorities were lenient when it came to granting permits. They approved the applications without taking into account either the wider developments in the nearby area or the existence of competing projects. The result was uncontrolled development, which sometimes led to an oversupply. Despite a more skeptical attitude toward the retail sector in general, the planning system for retail development in Central Europe is still highly fragmented and tends to be lenient toward new projects (Davies, 2004).

The liberalization of prices had an immediate impact on retail. When prices were determined by supply and demand instead of being administratively set, the shortage was replaced by a surplus. However, with real incomes declining, many goods became unaffordable to broad segments of the population. In many countries, it took 5-7 years before post-transition spending reached pretransition levels.

By deregulating the allocation of assets, retail trade was liberalized. Everybody was allowed to trade, and the countries opened their borders to international commerce in consumer goods. This immediately resulted in an increased supply and variety of merchandise and a greater number of retail outlets in the first years of the 1990s, as well as a substantial growth of the bazaar trade. It also paved the way for international retailers to enter the Central European markets.

The retail sector was subject to transformation and privatization throughout Central Europe. However, the strategy chosen in different countries reflected the range of ideological attitudes toward retailing and the divergent performance of the retail sector as such. The most straightforward path toward privatization was taken in the former Czechoslovakia. There, state-owned and 
collective retail organizations were split into smaller and more manageable parts, only to be privatized by auction afterwards. What contributed to the success was the strong moral position of the post-communist government but also the fact that state and cooperative retail businesses had value. However, privatization took longer in inner-city areas because of the restitution of confiscated properties to pre-socialist owners in many Czechoslovak city centers. The need for privatization in the former Czechoslovakia was ideological; it entailed transforming large-scale public entities into small-scale private entrepreneurial businesses. In Poland, the retail structure was so inefficient that business entities, inventories and stock would only be a liability. The only value-added element was the real estate itself, the shop unit. The spontaneous privatization in Poland after 1991 was therefore focused on a quick privatization of the real estate. This allowed bazaar traders, street traders and small entrepreneurs to take the place of the failed former state retailers. Riley (1997) found that almost all state and cooperative shop units in Central Lodz were privatized within 1 year after the initiation of the privatization process. The only exceptions were a couple of large units that were too big for private bidders to make an offer on at that time. Throughout Poland, the state and cooperative retail sector vanished almost completely within a year, as did the shortages and the long lines in front of the shops. The key issue in Poland was to replace the inefficient public retail system with a more efficient private retail supply. In Hungary, substantial parts of the cooperative retail sector were not included in the small privatization. Because of socialist reforms and the autonomous position of retail cooperatives, the retailers were quite successful and powerful. With a rather efficient retail system in place in Hungary, the retail privatization strategy was focused on keeping most of the organizations intact and maximizing the revenues of privatization. While some retail organizations have been sold to national and international investors, others have been privatized by management buy-outs. For example, the Austrian food retailer Julius Meinl bought the state-run food store chain Csemege in 1991. Even earlier, in 1989, the Belgian food retailer Louis Delhaize bought up Duna Füszért, a food store chain, to transform it into Profi discount stores. Some nonfood retail formats were privatized in the Fotex holding. As an outcome, many Hungarian retail chains from the socialist times continue to hold a prominent position in the local retail landscape today. While the key issue in the former Czechoslovakia was ideology and in Poland it was creating a functioning retail system, the key issue in Hungary was to raise revenue.

The transformation of the retail structure took place in subsequent waves, which Kreja (2004) interpreted as three distinct stages. Immediately after the political changes, there was a stage in which spontaneous trading was dominated by street and kiosk traders. Michalak (2001) referred to this as 'wild-east' phase. After several years, this was followed by a stage in which small shops and bazaars were established, indicating a trend of regulation in the market. And after the mid-1990s, there was a clear indication of Western-style retail unit expansion. This latest stage has been defined by the entry of Western retailers into the market and the development of Western-style retail property. 


\section{Trends on the consumer side}

Just as important as the transformation of the retail sector itself are the changes taking place on the consumer side. Though this will not be elaborated extensively in the present article, some of the key trends should be mentioned in order to complete the picture. The main ones are the following:

- Overall stagnant or declining population, limiting the demographic scope of the market. According to UN population forecasts, all Central European countries will be losing population in the coming years.

- Rising average spending power because of economic growth (see Figs. 1, 2 ), in particular after the mid-1990s. Those were the young and well educated persons who were able to reap most of the fruits of the new economic conditions. The rising spending power among the middle classes drove up the percentage of spending on non-food items and durables. That, in turn, attracted international non-food retailers to Central Europe.

- Increase in car ownership (see Fig. 3), one of the key parameters changing shopping behavior (Guy, 1998). More private car ownership allows the middle classes to visit large edge-of-town and out-of-town shopping centers and retail parks. This can change the shopping behavior of major segments of society in a short time. High and/or rising car ownership ratios among households is one of the key trends making out-of-town retail development feasible.

- Taking advantage of their regained freedom, Central European consumers tended to be very open to the new hypermarket and shopping mall. The mall was widely seen as a symbol of choice (Andrusz, 2006). Only after the first signs of failing projects appeared did the attitude towards uncontrolled retail development become more skeptical.

GDP growth (1990-2010 forecast)

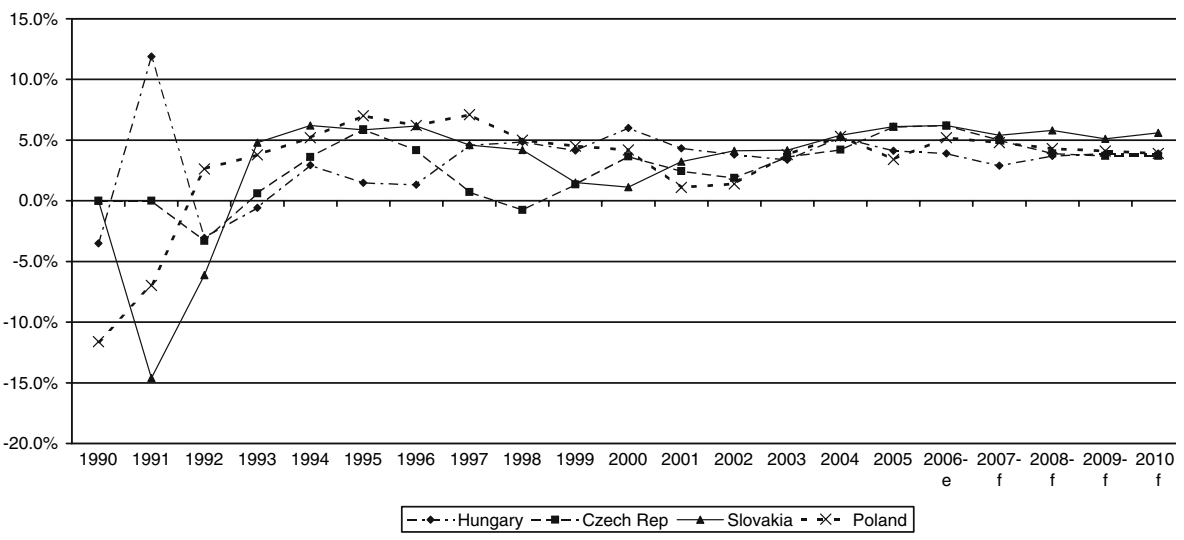

Fig. 1 GDP growth in Central and Southeastern Europe (1990-2010, forecast) Source: EIU, Economist Intelligence Unit 


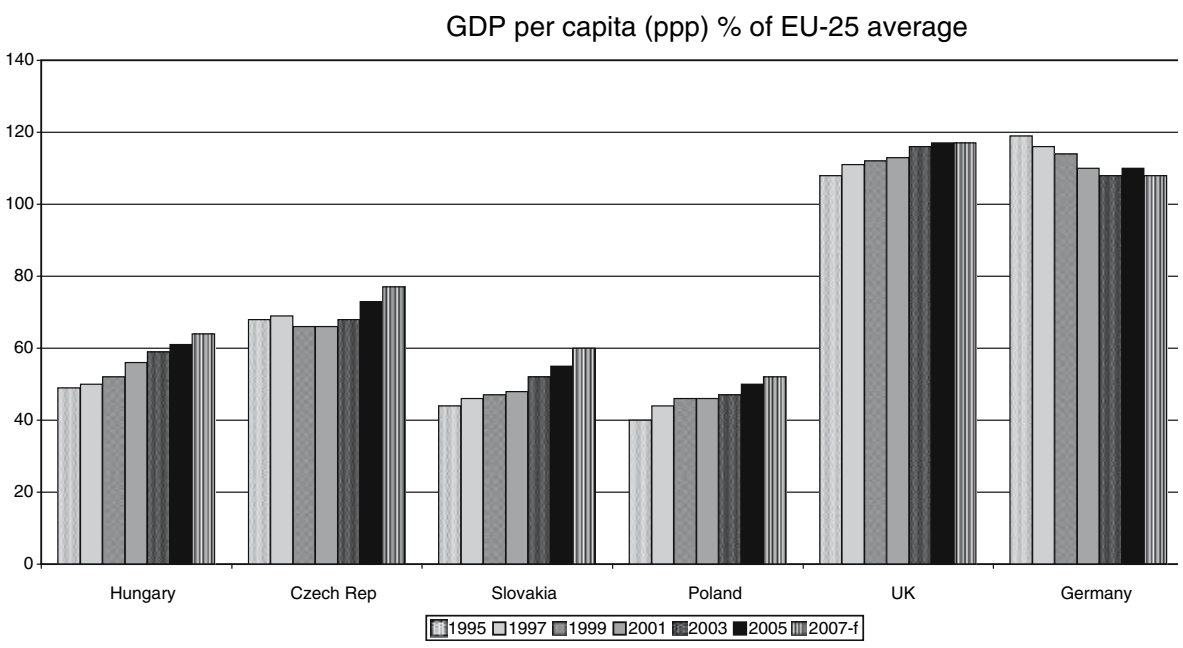

Fig. 2 GDP per capita (ppp, purchasing power parity) as \% of average EU-25 Source: EU, Eurostat

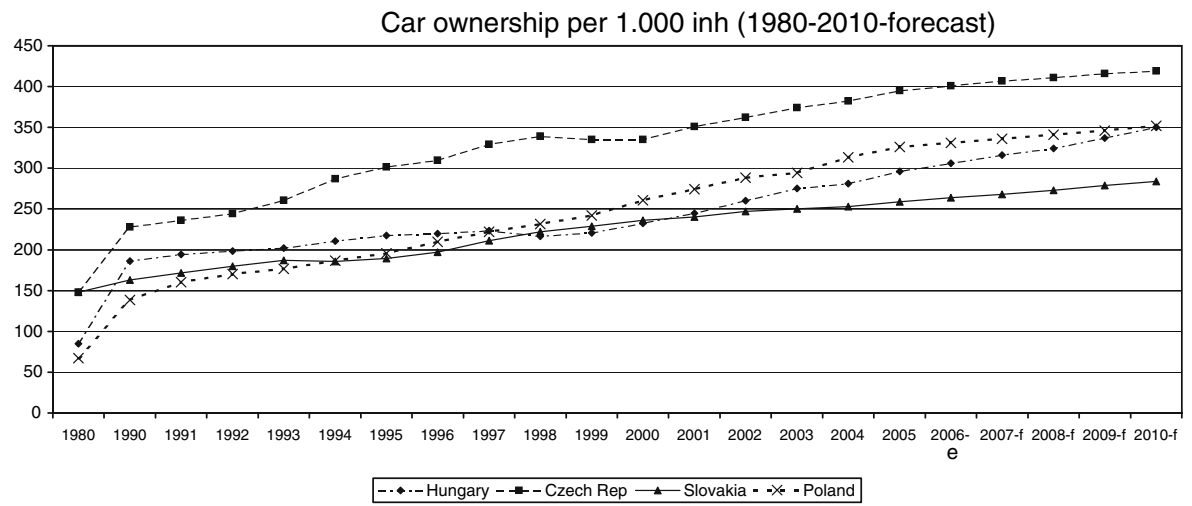

Fig. 3 Evolution of car ownership per 1,000 inh. (1980-2010, forecast) Source: EIU, Economist Intelligence Unit, Eurostat

- Intra-agglomeration migration patterns substantially changed the allocation of the population over metropolitan areas, as Kovács (2005) illustrated for Budapest. The population is declining in centrally located residential neighborhoods and socialist housing estates but increasing in garden cities and settlements near the city (suburbanization). This general trend has an enormous impact on the location criteria for shops, in particular for frequently visited convenience stores. Because of the massive edge-of-city and out-of-town opportunities, peripheral retail developments 
followed the first wave of suburbanization very quickly, or even preceded it in many cases (Garb \& Dybicz, 2006).

\section{Internationalization of the retail market in Central Europe}

After the transition of the retail market in Central Europe was completed, retail sales grew during the ensuing economic recovery (see Fig. 4), though the volume of the market is still limited compared to matured markets in Western Europe (Table 1). That enabled international retailers to enter the markets.

The Central European markets became prime targets for expanding retail corporations. Retail companies are driven by an ever-lasting need to grow (Howard, 2004). Growth is necessary to stay ahead of the competition; it is rewarded by higher market valuations, while a lack of growth is punished. Facing stagnant growth in their home markets, West European retailers were attracted to Central European markets. Limited growth, complicated retail planning, and tough competition pushed retailers into international expansion, while the growth of purchasing power, lack of local competition, relaxed planning systems, proximity to the home markets, and prospect of joining NATO and the EU were the main pull factors (McGoldrick, 1995). Table 2 shows that almost all leading retailers in Central Europe are under foreign ownership.

Only in Hungary is a local presence relatively strong, with three Hungarian retailers among the top ten. This pattern was reinforced by the fact that Hungarian retail organizations were relatively strong by the time of the transition and were privatized as single entity. But another reason is that the

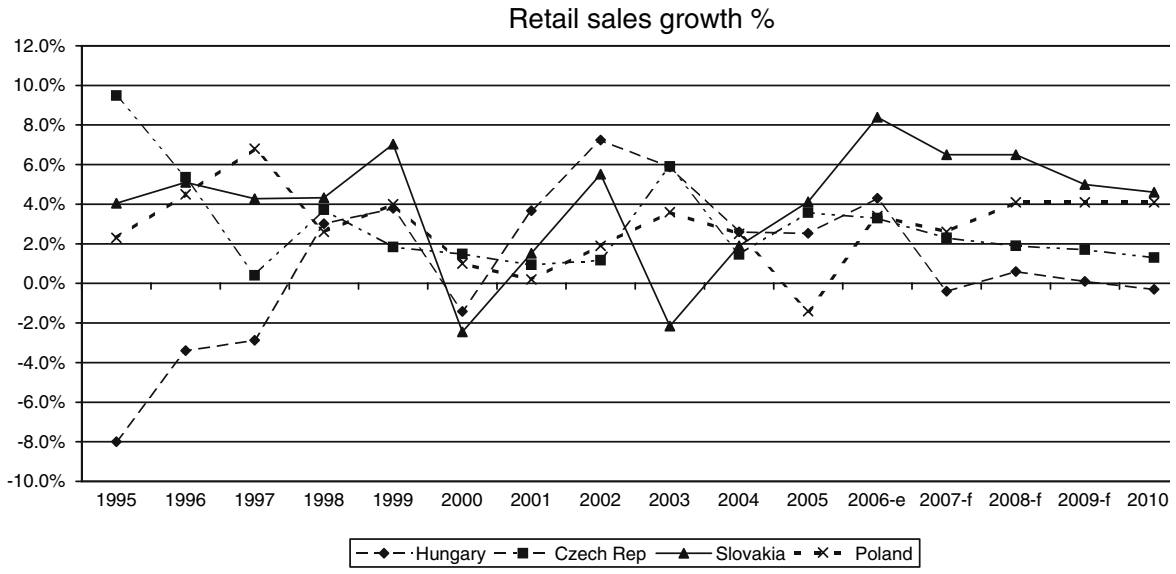

Fig. 4 Growth in retail sales 1995-2010 (\%) Source: Planet Retail-EIU Economist Intelligence Unit 
Table 1 Size of retail market and spending per capita

\begin{tabular}{lcclrl}
\hline Country & $2004 *$ bln euro & 2004 euro/ cap Country & $2004 *$ bln euro & 2004 euro/cap \\
\hline Czech Republic & 15 & 1.434 & Romania & 10 & 473 \\
Hungary & 18 & 1.733 & Bulgaria & 6 & 799 \\
Poland & 73 & 1.903 & Turkey & 83 & 1.150 \\
Slovakia & 9 & 1.647 & United Kingdom 327 & 5.473 \\
\hline
\end{tabular}

Source: Mintel (2005)

Table 2 Leading international food retailers in Central Europe

\begin{tabular}{|c|c|c|c|c|c|c|}
\hline \multicolumn{3}{|c|}{ 2004 Hungary } & \multicolumn{2}{|l|}{ Czech Republic } & \multicolumn{2}{|l|}{ Poland } \\
\hline & Retailer & Mln euroShops & sRetailer & Mln euroShops & s Retailer & Mln euroShops \\
\hline 1 & CBA & 2.836 & Makro (Metro) & 11 & Metro & 90 \\
\hline 2 & Tesco & 69 & Ahold & 231 & Jer. Martins & 725 \\
\hline 3 & Co-op & 4.487 & Lidl-Schwarz & 153 & Tesco & 78 \\
\hline 4 & Metro & 13 & Rewe & 222 & Lidl-Schwarz & 137 \\
\hline 5 & Real Hungaria & 1.840 & Tesco & 25 & Ruch & 12,298 \\
\hline 6 & Louis Delhaize & 211 & Globus & 12 & Carrefour & 87 \\
\hline 7 & Spar & 153 & Tengelmann & 130 & Auchan & 45 \\
\hline 8 & Auchan & 9 & Carrefour & 10 & Casino & 189 \\
\hline 9 & Tengelmann & 179 & Spar & 17 & Ahold & 193 \\
\hline 10 & Rewe & 142 & Delhaize & 97 & Tengelmann & 185 \\
\hline
\end{tabular}

* Domestic operators indicated in bold, Source: PriceWaterhouseCoopers (2005)

Hungarian market is relatively small and therefore not as aggressively targeted by foreign retailers as the markets of Poland and the Czech Republic.

The first wave of internationalization attracted mainly food retailers, do-ityourself retailers including Obi and Praktiker, and discount fashion, shoe and cosmetic brands, such as Rossmann, DM and Reno, as well as the consumer electronic discounter Mediamarkt.

Following the general economic growth, the expansion of hypermarkets, and the increasing availability of modern managed retail space, the Central European market became a strong target for international high-street nonfood retailers, particularly in the sphere of fashion retailing. Among these are brands like H\&M, Zara, and Saturn.

\section{Impact on the property scene}

Initially, the transition of retail trade mainly had an impact on the trade itself. First of all, this was a shift from shortage to surplus and the ability to have new goods in the market through imports. Many new traders in the market were selling on the street from stalls and kiosks or even cars. Furthermore, many of them took up stalls in bazaars, opened garage lockers and basements in 
housing estates, and took over privatized stores. Retail became highly fragmented, with a dramatic increase of outlets and entrepreneurs. Most of the enterprises were sole proprietorships with family support operating only one outlet. Retail traders relied mostly on wholesale markets-and later also on cash-and-carry stores like Metro-for their stock. However, these retailers were highly efficient in bringing new goods to market. Geographically, retail became highly fragmented throughout the city as well.

Except for functional changes in existing properties and the appearance of small outlets almost everywhere in the urban fabric, the transition also had an impact on the property market and urban structure. Traders were using existing outlets, were converting basements and garage lockers, or were establishing temporary stalls on the streets. However, after the initial years of the 1990s, bazaars selling both food and non-food items were extended in the lower and middle ranges of the market, and small shops were established at the upper end. The latter triggered some of the very first pioneering upmarket retail developments in Central Europe. Shopping centers like Budagyöngye in Budapest and Panorama in Warsaw were among the first retail developments in the cities. These developments were based on small boutique-style shops positioned high in the market targeting high-income groups who traveled to the West for much of their shopping. They are located in or close to areas where high-income groups live and are easy to reach by car. As large retailers were lacking in the market, these schemes lacked anchor-store positions within the projects. These projects were followed by many more and bigger shopping centre projects.

The arrival of international retailers in Central Europe had a more definite impact on the market. Among the first arrivals were supermarket operators, such as Meinl and Tengelmann (Plus discounters, Kaiser supermarkets) in Hungary, Ahold in the Czech Republic, and Biedronka (Jeronimo Martins) in Poland. Most of these supermarket retailers initially accepted existing food-store properties or well located low-priced warehouse properties. The main objective was to establish a position in the market through quick expansion.

However, the arrival of large cash-and-carry, do-it-yourself (diy) and hypermarket brands after the mid-1990s had a more pronounced impact. These retailers needed properties with sales areas of at least $5,000 \mathrm{~m}^{2}-$ $15,000 \mathrm{~m}^{2}$ with additional storage capacity on well accessible locations. As such properties did not exist, they had to be newly developed. From the mid1990s on, a wide range of hypermarket operators-e.g., Cora, Tesco, and Auchan in Hungary-started to target Central Europe. Cities like Warsaw became dotted with big box retail developments (Kreja, 2006).

Table 3 shows the enormous growth in the number of hypermarkets in Central Europe. After an initial focus on the capital cities and the largest cities, hypermarket operators shifted to secondary and tertiary cities to establish nationwide networks. The fastest-growing operators in Central Europe are Tesco and Auchan (in Poland and Hungary). 
Table 3 Hypermarket supply (number of hypermarkets)

\begin{tabular}{lrrrrrrrrr}
\hline 1995 & 1996 & 1997 & 1998 & 1999 & 2000 & 2001 & 2002 & 2003 & 2004 \\
\hline Hungary & 2 & 5 & 14 & 24 & 36 & 44 & 55 & 63 & 76 \\
Czech Republic & 1 & 2 & 7 & 25 & 51 & 82 & 130 & 145 & 160 \\
Poland & 30 & 42 & 65 & 95 & 112 & 136 & 141 & 202 & 240 \\
\hline
\end{tabular}

Source: PriceWaterhouseCoopers, GFK, Mintel

Table 4 Shopping center supply $\left(* 1,000 \mathrm{~m}^{2}\right.$ GLA, gross leasable area)

\begin{tabular}{lrrrrrr}
\hline & 1997 & 1999 & 2000 & 2002 & 2005 & est 2007 \\
\hline Hungary & 270 & 450 & 575 & 603 & 900 & 1,012 \\
Czech Republic & 65 & 220 & 300 & 557 & 1,101 & 1,409 \\
Poland & 150 & 700 & 1,750 & 2,414 & 3,942 & 5,539 \\
\hline
\end{tabular}

Source: Cushman \& Wakefield (2006)

Throughout Central Europe, various factors coincided to facilitate capital accumulation through investment in property (Tasan-Kok, 2006). Basically, the fragmented and decentralized planning system combined with a municipal hunger for capital and investment in a competitive economic environment driven by international retailers and investors. The outcome was-as shown Table 4-a tremendous increase of shopping centre supply in the late 1990s and early years of the new millennium Until now, the big-box retailers and developers have mostly targeted 'easy' project locations; these include locations without ownership issues and urban sites where the necessary infrastructure is already in place. The point is to get the quickest result without running a risk that the public authorities will not be able to deliver the planned infrastructure or ending up in more complicated procedures.

\section{Transformation of the shopping scene: the example of Budapest}

Budapest is one of the Central European capitals that has undergone dramatic change in the retail structure. In about 10 years, 30 shopping centers were established with a total floor space of $615,000 \mathrm{~m}^{2}$ GLA (Jones Lang LaSalle, 2006). Meanwhile, about 25 hypermarkets opened up in and around the city, representing another $200,000 \mathrm{~m}^{2}$. The retail structure of Budapest was completely transformed (see Fig. 5), and the buying behavior of the majority of the population was completely overhauled in this period.

Initially, the structural changes in the retail trade were mainly manifest in ownership patterns. The existing retail supply changed hands and the first generation of international retailers entered the market. Regarding real estate, the changes were limited though visible. Initially, many existing street bazaars were expanded and new ones were opened. Bazaars became the prime source of consumer goods, particularly groceries. Furthermore, many small entrepreneurs started up small-scale retail outlets. Some were located in 

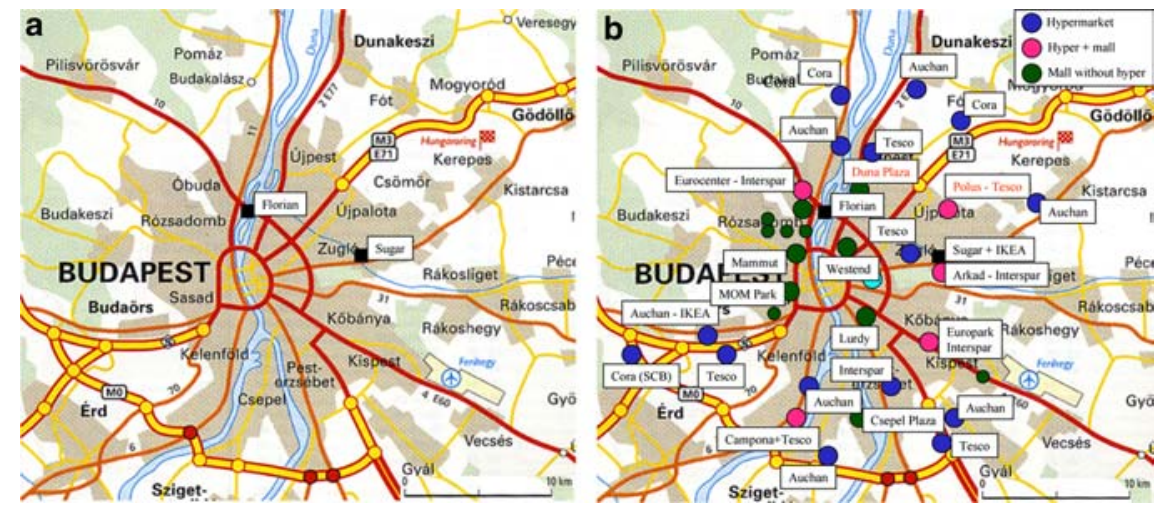

Fig. 5 Shopping center development in Budapest: 1990-2005. (a) Shopping centers in Budapest in 1990; (b) Shopping centers in Budapest in 2005

existing outlets on the street, in converted basement spaces in apartment blocks or in garage lockers; others were in kiosks clustered together at either metro stations or at the main tram and bus hubs. The average size of these new retail outlets was very small, well below $50 \mathrm{~m}^{2}$.

The early international food retailers in the market included Julius Meinl and Spar from Austria, Plus (Tengelmann) from Germany, and Profi (Louis Delhaize) from Belgium. Initially, they secured existing retail space by taking over state-owned food retail chains such as Csemege and Duna Füszért. Though most of the real estate was outdated, it still fulfilled the basic needs of the first retailers, whose prime concern was to have outlets at existing locations that are highly frequented.

\subsection{The first signs of shopping center development}

After some years of stagnation, there were some signs that real estate development was coming back to life. International supermarket operators had entered the market and most of the existing outlets were outdated. Retailing started to draw some attention. Local developers got involved in the construction of new buildings or the refurbishment of existing ones. The latter were turned into small-scale retail centers with very small boutique-style units and no larger anchor stores. Most of these units were sold or leased to independent private entrepreneurs to be operated as shops. Retail galleries were developed throughout the city, mainly at highly frequented locations, such as along the Nagykörut in the city center and in Obuda near Kolosy square. The largest early retail development in Budapest was Budagyöngye, which opened in 1994 in the high-income area of Rozsadomb.

The first international 'big-box' retailers-i.e., retailers that sell from a very large sales area-to arrive in Hungary were chains: Metro (cash-and-carry); Obi (do-it-yourself); and Baumax (do-it-yourself). The only way for them to open new stores was to develop them themselves. This was when some of the 
first cash-and-carry and do-it-yourself stores were built in the city. Because of the large amounts of land they required, these stores tended to be located at the edge of the city on the main arterial road, although some successful developments can be found on brownfield sites.

\subsection{Late 1990s: shopping center and hypermarket development boom}

The first (international) developers started to discover the opportunities to develop shopping centers. A that time, the existing retail supply was of low quality, mostly in outdated properties in unattractive environments. The newly developed retail galleries were not suitable for professional (international) retail chains. Even the high-street areas were not considered attractive. One of their disadvantages was the unclarified owner and tenant rights in many buildings, a legacy of the former berleti jog system. ${ }^{1}$

Other disadvantages were outdated street furniture, pollution, and a lack of safety and security. These developers took advantage of the opportunity that arose when the first international retailers present in the market started to consider the need for new locations and real estate, while many other retailers were only willing to consider the Hungarian market if modern retail space would be made available.

Local governments were eagerly looking for investments, and shopping centers were a prime source of identity and prestige for them. The 23 districts in Budapest, as well as some of the 71 settlements in the surrounding agglomeration, wanted a share of the development of new retail and shopping centers. As the division of responsibilities between different levels of urban government was not transparent, competition and conflicts over developments were common. The outcome was a rapid and uncontrolled boom in retail and shopping center development (Keresztély, 2002).

The first real shopping center to open in Budapest was Duna Plaza. This $35,000 \mathrm{~m}^{2}$ gross leasable area shopping center was built in a brownfield area north of central Budapest. Duna Plaza was developed as an Israeli-Hungarian joint venture. The shopping center-initially referred to as Little America in Angyalföld-is well accessible because there is a metro station out front. Despite initial doubts about its commercial feasibility, the center was an enormous success. Because of the multiplex cinema and the food court, the center appealed to young adults. Duna Plaza turned out to be an important trigger for the revitalization of the Vaci ut area. The whole area was transformed from a derelict industrial and warehouse district into the prime office axis of Budapest in a matter of 5 or 6 years.

However, the competition did not wait long to join in. Polus Center, developed as a Hungarian-Canadian joint venture, opened only 1 month later.

\footnotetext{
${ }^{1}$ Berleti jog: use right (leasehold) of retail space. In Hungary given to a user during the socialist period for an indefinite time at low rent with strong user rights, including right to sublease. Berleti jogs continued after the political transition, with most of the berleti jog holders subleasing their units. A non-transparent market was the outcome. This is not elaborated in the framework of this paper.
} 
But its location in the northeast of the city, close by the motorway to Miskolc, makes the center less successful, as it lacks good public transport access.

Europark, developed by the Austrian company Illbau, opened four months later (in March 1997) in the manly lower-income southeast part of the city. This center-anchored by the Austrian Interspar hypermarket, Mediamarkt, and Hervis (an Austrian sporting goods chain) proved successful from the very beginning. Its excellent car and public transport access-like Duna Plaza, Europark is connected to the metro-and a price-driven brand mix made this center well accessible for the Hungarian middle class.

Tesco, Budapest's first hypermarket, opened to the east of the city center in the middle-class area of Zuglo in 1995. Belgian-French operated Cora opened the first out-of-town hypermarket in Törökbalint, $15 \mathrm{~km}$ southwest of Budapest. This initiative was followed by two more Cora outlets: one in Budakalász to the north and the other in Fót northeast of the city. The key reasons for Cora to go out-of-town were lower land prices and easier procedures to obtain planning permission from the local authorities. Cora Budakalász, a hypermarket having a catchment area of about 400,000 consumers (mostly from Budapest), was permitted by Budakalász municipality, representing 6,000 inhabitants itself.

In the following years, a number of smaller schemes were developed catering to the neighborhood population. Three of these-Rozsakert (Rozsadomb), Uj Udvar (Ujlak), and Retkoz (Gazdagret)—were carried out by small foreign development companies. Most of these schemes were positioned too up-market for their respective catchment areas. They encountered vacancy problems because of poor location, poor access, and conceptual design issues. Local governments started to realize that retail developments could fail as well, thereby creating problems for the area.

Several larger schemes were added to the market in 1998 and 1999. One successful project, called Mammut, was doubled in size by an extension in 2002. A centrally located urban scheme, close to the metro station in Buda, became the prime center for wealthy customers from the Buda hills. The scheme was developed by a Hungarian development consortium and was supported by foreign loans. The project was triggered by the opportunity to redevelop an outdated street bazaar. When the old Fény Piac street bazaar disappeared, the new Fény bazaar was attached to the shopping center in its own structure; there, vendors can sell their goods from modern, hygienic stalls and kiosks. Westend City Center, the premier shopping mall of Budapest, opened in 1999. It has an excellent location next to the Western Railway Station, with a direct connection to the Budapest metro and tram system. Westend, developed by the Hungarian-Canadian joint-venture company Trigranit, is a multifunctional project with shopping, urban entertainment, a hotel, and office space. Its in-town location adjacent to the central city and the high quality of public space in and around it make Westend a landmark project in Budapest. Its success is striking, considering that it opened in 1999, still an early phase in the market, though the retail supply in the scheme is not much different from that in other schemes elsewhere in Budapest. This is a 
good example of the dilemma that most of the developers are facing. On the one hand, they are under pressure to create an urban landmark with a unique identity. On the other hand, they need to bring in international and national brands because investors want them (Andrusz, 2006), as do many municipalities and the majority of the consumers.

Akrád, another key center, was developed by the German firm ECE. It is a $40,000 \mathrm{~m}^{2}$ GLA scheme lying at the eastern terminus of the red metro line on Örs Vezer square. It is located right opposite the existing Sugár scheme. But the street between the two projects is a district boundary between two districts, each having their own planning authority. The scheme is performing well because of the strong retail concept and the fact it brought many new international (German) retailers into the market.

The redevelopment of the Feny Piac street bazaar in the Mammut project is an example of the gradual modernization of the most important marketplaces in the city. Since then, several historic markets have been refurbished and modernized without losing their original function (e.g., the historic Vasarcsarnok). Several 'newer' ones have been completely redeveloped as modern new marketplaces: one is Lehel square nearby the Western Station; another is Fehervari marketplace in southern Buda. While bazaar trading is under severe pressure in other Central European countries, the bazaar trade is creating its own niche in the retailing market thanks to local government backing for the revitalization of marketplaces. These are commercial areas targeting the lowest income groups. The associated quality of the fresh food, the atmosphere of the place, and the proximity to residential areas have made the marketplaces destinations for a broad spectrum of society.

Parallel to the wave of shopping center development, two hypermarket operators-namely Tesco and Auchan-established their networks in and around Budapest. Currently Tesco has nine stores and Auchan eight; both firms have several more under development. The hypermarkets are mostly located at the edge of town or just outside town. The hypermarkets have become the main nodes of one-stop shopping in Budapest.

As the supply of shopping centers reaches a high level, retail developers create new concepts to attract potential retail tenants and convince planning authorities of the need for more. The Belgian group Lenaers introduced the concept of the factory outlet center to Hungary, developing Hungary's first one on the southwestern outskirts. And the Israeli firm Albion introduced the strip mall concept to the market by integrating several large-area retail outlets into one complex. Albion aims to develop its strip mall concept at existing power and hypermarket locations, such as the site of Auchan in Soroksár.

Retail developers are preparing themselves for more complicated landmark projects in the urban core. The Dutch developer ING is developing Vörösmárty square by replacing a socialist-style office block in the heart of Budapest with a $30,000 \mathrm{~m}^{2}$ contemporary complex including space for retail, offices, and apartments. A Hungarian development company is working on the rejuvenation of the southern section of Józsefvaros. And there are plans to revitalize the City Hall area, a central city site that has been under discussion 
for many years. Already one of the strongest city center landmark sites in Budapest, a well-established urban development vision and commitment among the actors will add to the long-term quality of this project. However, the fragmented planning systems and the lack of a widely shared vision on how the city will look in the future cast a shadow on the prospects for mixeduse urban landmark projects.

\section{Conclusions}

The transformation and globalization of the retail market have had a tremendous impact on urban retail patterns and continue to have an impact on local urban development. The number of retail outlets grew enormously just after the change (in Hungary starting earlier). Though the number of outlets has been more or less stable over the past 10 years, the sales area continues to increase. This is because of the construction and extension of larger stores and the closure of smaller stores. Globalization-the internationalization of the retail trade-encouraged many retailers from Western and Northern Europe to expand into Central Europe. As these retailers had access to capital to invest and a need for high-quality retail space at strong locations, the arrival and growth of international retailers was a major impetus for retail real estate development.

The scale and the edge-of-town location of hypermarket developments in particular have changed the retail landscape. The actors were international hypermarket retailers and developers. Their initiatives were supported by the growth of purchasing power and an increase of car ownership and car use. For many households, going shopping changed from an errand done on foot or public transport to a car-based activity. Locations on primary arterial roads at the edge or just outside the city were easy to develop because they were subject to quick planning and permitting procedures. They subsequently became prime out-of-town shopping locations. These hypermarket locations were so popular that they grew into retail park locations, as other large stores located there too.

Some other locations developing into retail nodes were urban sites with a combination of good access by car and public transport (metro); these were the main focal points for shopping center developers. Urban shopping mall development was triggered by the combination of a strong location and a redevelopment opportunity, particularly in the case of a closed down factory or bazaar to be redeveloped. These schemes became successful fun-shopping nodes and important places for the local population to meet. Prime high-street areas made the transition from heterogeneous retail areas into fashion- and brand-dominated retail areas similar to the prime high streets in Western Europe.

Some retail locations are losing strength. These are the centrally located non-prime high-street retail areas, as well as the socialist housing estate retail facilities without good car access. Many of these outlets have closed down. 
The space is now used for services or catering, or it simply remains empty. After the initial success, many of the kiosks and container-type shops closed down. Hypermarkets, supermarkets, and other modern formats absorbed their market share, although some of the pioneering convenience stores in densely populated areas and housing estates are still operating.

Planning was decentralized to the lowest level of local government. As the plans were geared to attracting capital, investments and employment to the locality, they were highly fragmented and favored new development. However, the population was becoming skeptical about new edge-of-town shopping center developments. Moreover, there were clear signs of oversupply in the market. In that light, planning is becoming less amenable to new development. Local authorities have become increasingly involved in the revitalization and redevelopment of central sites, which often demonstrate a high level of complexity and require much sensitivity. In such projects, retail is often an important source of revenue because of their rental and investment value. Thus, retail is often an essential element in the program to make the project feasible. Local authorities, urban planners and developers will have to coordinate their visions on how to deal with the evolution of the retail property in relation to the urban structure. What is needed is a good understanding of how retailing works in the urban environment. Also needed are long-term commitment and vision among policy-makers, planners and developers. And it must be acknowledged that investors and key end-users play an important role in the process. Only when all of these conditions are met could urban mixed-use projects be successful in the future.

\section{References}

Andrusz, G. (2006) Wall and mall: A metaphor for metamorphosis. In S. Tsenkova \& Z. NedovicBudic (Eds.), The urban mosaic of post-socialist europe (pp. 71-90). New York/Heidelberg: Physica Verlag.

Bertaud, A. (2004) The Spatial Structures of Central and Eastern European cities: More European than Socialist? Paper presented at conference "Winds of Societal Change: Remaking Post-communist Cities". University of Illinois at Urbana-Champaign June 17-19.

Bertaud, A., \& Renaud, B. (1995) Cities without land markets: Location and land use in the socialist city. New York. Worldbank. Policy Research Working Paper No 1477. .

Cushman \& Wakefield (2006) Shopping Centre Supply in Europe - June 2005 (data). London: Cushman \& Wakefield.

Davies, R. (2004) Planning policy for retailing. In J. Reynolds \& Chr. Cuthbertson (Eds.), Retail Strategy: A view from the bridge (pp. 78-95). Amsterdam: Elsevier.

Deiters, J. (2000) Budapest und Prag - Stadtentwicklung in der Marktwirtschaft.

Earle, J. S., Frydman, R., Rapaczynski, A., \& Turkewitz, J. (1994) Small privatization: The transformation of retail trade and consumer services in the Czech Republic, Hungary and Poland. Budapest: Central European Press.

EIU Economist Intelligence Unit: Market Information Forecast database (accessed in 2006). London/New York: Economist.

Eurostat (1996) Retailing in the Central European countries. Luxembourg: Eurostat.

Eurostat (2006) Statistics on national accounts (accessed in 2006). Luxembourg: Eurostat.

Garb, Y., \& Dybicz, T. (2006) The retail revolution in post-socialist Central Europe and its lessons. In S. Tsenkova \& Z. Nedovic-Budic (Eds.), The Urban Mosaic of Post-Socialist Europe (pp. 231-252). New York/Heidelberg: Physica Verlag. 
Guy, C. M. (1998) Controlling new retail spaces: The impress of planning policies in Western Europe. Urban Studies (35, 5-6), 953-979.

Howard, E. (2004) Retail internationalization: How to grow. In J. Reynolds \& Chr. Cuthbertson (Eds.), Retail Strategy: A view from the bridge (pp. 96-118). Amsterdam: Elsevier.

Jones Lang LaSalle (2006) Budapest City Profile March 2006. London, Jones Lang LaSalle.

Keresztély (2002) The role of the central government in the urban development of Budapest. Unpublished research report. SOROS Research Support Scheme Program, RSS No. 359/1999.

Kornai, J. (1992) The Socialist System: The Political Economy of Communism. Princeton University Press.

Kreja, K. (2004) Changes in spatial patterns of urban consumption in post-socialist cities: New large-scale retail development in Warsaw. Paper presented at Conference: "Winds of Societal Change: Remaking Post-Communist Cities" University of Illinois, June 18-19.

Kreja, K. (2006): Spatial imprints of urban consumption: Large-scale retail developments in Warsaw. In S. Tsenkova \& Z. Nedovic-Budic (Eds.), The urban mosaic of post-socialist europe (pp. 253-272). New York/Heidelberg: Physica Verlag.

Kovács, Z. (2005) Population and housing dynamics in Budapest metropolitan region after 1990. Paper prented at ENHR conference. Reykjavik, Iceland.

McGoldrick, P. J. (1995) Introduction to international retailing. In P. J. McGoldrick \& G. Davies (Eds.), International retailing: Trends and strategies (pp. 1-13). London: Pitman Publishing.

Michalak, W. Z. (2001) Retail in Poland: An assessment of changing market and foreign investment conditions. In Canadian Journal of Regional Science/Revue canadienne des sciences régionales, XXIV: 3, 485-504.

Mintel (2005) European retail handbook 2005/6. London: Mintel.

PriceWaterhouseCoopers (2005) From Beijing to Budapest: Winning brands, winning formats.

Riley, R. (1997) Central area activities in a post-communist city: Lodz, Poland. Urban Studies, 34(3), 453-470.

Sýkora, L. (1994) Local urban restructuring as a mirror of globalization processes: Prague in the 1990s. Urban Studies, 31(7), 1149-1166.

Tasan-Kok, T. (2006) Institutional and spatial change. In S. Tsenkova \& Z. Nedovic-Budic (Eds.), The urban mosaic of post-socialist Europe (pp. 51-70). New York/Heidelberg: Physica Verlag. 